\title{
NOTES
}

\section{EMPLOYEE BARGAINING POWER UNDER THE NORRIS-LAGUARDIA ACT: THE INDEPENDENT CONTRACTOR PROBLEM*}

THE Norris-LaGuardia Act permits union monopoly of the labor market. ${ }^{1}$ Designed to insure effective collective bargaining, the statute extends antitrust immunity only to unions organized and acting to promote the terms and conditions of employment. ${ }^{2}$ Implementing this limitation, courts have barred independent contractors from organizing themselves and collectively fixing the

*United States v. Fish Smokers Trade Council, Inc., Crim. No. 148-208, S.D.N.Y., Oct. 15,1956 (subsequently restored to trial calendar).

1. 47 STAT. 70 (1932), 29 U.S.C. $\$ \$ 101-13$ (1952). The act is designed to encourage self-organization. Section 102, in describing the policy of the act, states: "It is necessary that he [the worker] have full freedom of ... self-organization ...." 47 STAT. 70 (1932), 29 U.S.C. \& 102 (1952). See Colorado-Wyoming Express Co. v. Denver Local 13, Int'1 Brotherhood of Teamsters, 35 F. Supp. 155 (D. Colo. 1940). Freedom of self-organization gives unions power to obtain a monopoly in the labor market. See Machlup, The PolrTICAL ECONomy of Monopoly 333-33 (1952) (hereinafter cited as Machlup) ; Mason, Economic Concentration and the Monopoly Problem 196-200 (1957) (hereinafter cited as Mason); Cox, Labor and the Antitrust Lazes-A Preliminary Analysis, 104 U. PA. L. REv. 252, 254 (1955) ; Comment, 54 Y ALE L.J. 853 (1945). A union, however, is not a monopoly in the same sense as a business operating in the product market. It does not sell, but only negotiate's for the sale of, labor. It is also limited in monopoly power by the difficulty of maintaining cohesiveness in an organization composed of a large number of individuals. Nevertheless, it still is a monopoly. Mason 200-03. See also Machlup 341-42 (failure to use the term "monopoly" in connection with labor unions is chiefly a matter of sensitivity about words which have acquired unpleasant connotations).

2. Originally, the Sherman 'Act was frequently applied to labor. See Loewe v. Lawlor, 208 U.S. 274 (1908) ; United States v. Workingmen's Amalgamated Council, 54 Fed. 994 (C.C.E.D. La. 1893). And the Clayton Act did not materially improve labor's position in the courts. See Bedford Cut Stone Co. v. Journeymen Stone Cutters' Ass'n, 274 U.S. 37 (1927) ; Duplex Printing Press Co. v. Deering, 254 U.S. 443 (1921). The validity of these decisions was often challenged. Steffen, Labor Activities in Restraint of Trade: The Apcr Case, 50 Yale L.J. 787, 825 (1941). See Beratan, Labor and The Sheraran Act (1930); Frankfurter \& Greene, The Labor Injunction 199-278 (1930); Boudin, The Shcrman Act and Labor Dispntes, 39 CoLUM. L. Rev. 1283 (1939). The Norris-LaGuardia Act was passed as a reaction to the courts' restriction of the rights granted to labor in the Clayton Act. H.R. Rep. No. 669, 72d Cong., 1st Sess. $2-5$ (1932) ; United States v. Hutcheson, 312 U.S. 219, 236 (1941) ; Etter, Statutory Defintitions of "Labor Dispute," 19 ORE. L. REV. 201, 229-44 (1940). Whether antitrust laws should be applicable to unions in any manner is still a matter of debate. Kelley \& Cranfield, Should Labor Unions bc Subject to Antitrust Laws?, Mich. State B.J., Jan. 1957, p. 24.

Nevertheless, Norris-LaGuardia provide's: "No court . . . shall have jurisdiction to issue any restraining order or permanent injunction in a case involving or growing out of a labor dispute." 47 Stax. 70 (1932), 29 U.S.C. \& 101 (1952). "The term 'labor dispute' includes 
price at which they sell their product. ${ }^{3}$ The absence of an employer-employee relationship has led to holdings that these activities concern terms and conditions of sale rather than employment. ${ }^{4}$ Decisions have even cast doubt on the legality of attempts by employee unions to organize competing independent

any controversy concerning terms or conditions of employment ... whether or not the disputants stand in the proximate relation of employer and employee." 47 STAT. 73 (1932), 29 U.S.C. $\$ 113$ (c) (1952).

Section 113 not only prohibits injunctions but also exempts parties involved in a labor dispute from other types of antitrust censure. Section 20 of the Clayton Act, making nonenjoinable activities legal, has been held to embrace activities which fall within the NorrisLaGuardia definition of a "labor dispute." United States v. Hutcheson, supra; Steffen, Labor Activitics in Restraint of Trade: The Hutcheson Case, 36 ILL. L. Rev. 1. (1942) (criticizing this statutory importation).

Disputes have been found in various situations. Donnelly Garment Co. v. Dubinsky, 154 F.2d 38 (Sth Cir. 1946) (organizational activities); Beun v. Fur Workers Union, 24 CCH Lab. Cas. $\{67795$ (D.D.C. 1953) (organizational picketing of an employer before he began to hire employees) ; New Negro Alliance v. Sanitary Grocery Co., 303 U.S. 552 (1938) (picketing in protest of racial discrimination in hiring); United States v. Carrozzo, 37 F. Supp. 191 (N.D. Ill.), aff'd sub nom. United States v. International Hod Carriers Council, 313 U.S. 539 (1941) (attempt to curtail automation); Diamond Full Fashioned Hosiery Co. v. Leader, 20 F. Supp. 467 (E.D. Pa. 1937) (peaceful picketing in protest of sale of plant machinery) ; Levering \& Garrigues Co. v. Morrin, 71 F.2d 284 (2d Cir.), cert. denied, 293 U.S. 595 (1934) (urging another union to engage in a sympathy strike); Matson Nav. Co. v. Seafarers Union, 100 F. Supp. 730 (D. Md. 1951) (retaliatory picketing); Houston \& North Texas Motor Freight Lines v. Local 886, Int'l Brotherhood of Teamsters, 24 F. Supp. 619 (W.D. Okla. 1938) (minority union strike against majority union which had a contract with the employer); Yoerg Brewing Co. v. Brennan, 59 F. Supp. 625 (D. Minn. 1945) (strike to coerce employer to refuse recognition of rival union certified by NLRB) ; Meier \& Pohlmann Furniture Co. v. Gibbons, 113 F. Supp. 409 (E.D. Mo. 1953), aff'd, 233 F.2d 296 (Sth Cir.), cert. denied, 352 U.S. 879 (1956) (employee refusal to handle goods of another firm); Alcoa S.S. Co. v. MoMahon, 81 F. Supp. 541. (S.D.N.Y. 1948), aff'd, 173 F.2d 567 (2d Cir.), cert. denied, 338 U.S. 821 (1949) (strike in violation of contract terms); Hunt v. Crumboch, 325 U.S. $\$ 21$ (1945) (union forbade members to work for employer suspected of murdering union official, thereby forcing him out of business). But see, in contrast to Yoerg Brewing and Meier Furniture, Oberman \& Co. v. United Garment Workers, 21 F. Supp. 20 (W.D. Mo. 1937) ; Loews Inc. v. Basson, 46 F. Supp. 66 (S.D.N.Y. 1942).

3. See, e.g., Columbia River Packers Ass'n v. Hinton, 315 U.S. 143 (1942) ; Gulf Coast Shrimpers and Oystermans Ass'n v. United States, 236 F.2d 658 (5th Cir.), cert. denied, 352 U.S. 927 (1956) ; Hawaiian Tuna Packers v. International Longshoremen's Union, 72 F. Supp. 562 (D. Hawaii 1947). See also American Medical Ass'n v. United States, 317 U.S. 519 (1943).

4. Although an employee-employer relationship is not required for the existence of a labor dispute, the absence of such a relationship or of the possibility of such a relationship precludes classification of the dispute as concerning terms or conditions of employment. Columbia River Packers Ass'n v. Hinton, supra note 3, at 146-47. In Hawaiian Tuna Packers v. International Longshoremen's Union, supra note 3 , at 566, independent fishermen attempted to organize both themselves and a few crew members in one union. The court rejected the contention that since the crew's wages depended on the selling price of fish, disputes between the "union" and purchasers were "labor disputes" concerning conditions of employment. 
contractors ;" for combinations of "labor" and "non labor" groups which benefit the latter interest are not relieved from Sherman Act stricture by the existence of a labor dispute. ${ }^{6}$ Although the courts have retained considerable discretion by manipulating the definition of independent contractor, ${ }^{7}$ interpretations of the Norris-LaGuardia Act which restrict the ability of employee unions to organize contractors have recently been criticized as unduly limiting union control of the labor market. 8

5. Federal courts have never directly faced this problem. In the only case involving an employee union organizing competing vendors, the Supreme Court found that the vendors were, in economic reality, employees and therefore subject to unionization. Milk Wagon Drivers' Union v. Lake Valley Farm Products, Inc., 311 U.S. 91 (1940), 26 IowA L. REv. 411 (1941). The application of this decision to independent contractors, generally, is doubtful. Compare Barnes, Unions and the Antitrust Lazws, 7 LAB. L.J. 133, 175-76 (1956) (union organizing independent contractors probably not a labor dispute), with Aetna Freight Lines, Inc. v. Clayton, 228 F.2d 384 (2d Cir. 1955), cert. denied, 351 U.S. 950 (1956) (broad policy of the Milk Wagon case sustains the legality of employee picketing to force independent contractor acceptance of union regulations on working conditions).

6. Allen Bradley Co. v. Local 3, Int'1 Brotherhood of Electrical Workers, 325 U.S. 797 (1945) (electrical workers local in combination with electrical fixture manufacturers employing its members enjoined from forcing contractors to use only fixtures made by the combined manufacturers); United Brotherhood of Carpenters v. United States, 330 U.S. 395 (1947) (combination of employees and employers to prevent out-of-state manufacturers from shipping and selling lumber in San Francisco held illegal); Philadelphia Record Co. v. Manufacturing Photo Engravers Ass'n, 155 F.2d 799 (3d Cir. 1946) (combination of union and employers' trade association forcing nonmember engravers to charge prices set by the association enjoined); United States v. Milk Drivers Union, 6 CCH LAB. L. REp. \I 70934 (D. Minn. Aug. 30, 1957) (combination of union and dairy distributors, with union acting as a policing agent to require retail stores to maintain noncompetitive consumer prices, held illegal). See also Comment, 19 So. Cal.r. L. REv. 256 (1946); 56 Colurr. L. REv. 280 (1956).

A union, however, might be able to procure agreements from employers individually without violation, even though the Sherman Act would probably be violated if it obtained the same agreements from the employers collectively. East Texas Motor Freight Lines v. International Brotherhood of Teamsters, 163 F.2d 10 (5th Cir. 1947); Allen Bradley Co.v. Local 3, Int'1 Brotherhood of Electrical Workers, supra at 810-11 (dictum). Commentators differ on whether such "individual" employer agreements should be permitted. See Barnes, supra note 5 , at 135 (opposed) ; Cox, supra note 1, at 270-71 (negotiating parallel agreements effecting market control should not violate the Sherman Act).

7. E.g., Mitchell v. Gibbons, 172 F.2d 970 (8th Cir. 1949) (taxi drivers who leased their cabs, worked anywhere within the lessor's franchise and made no accounting of their fares to the lessor held lessor's employees and allowed to organize). See Hotel Stanley v. Bright, 25 CCH Lab. Cas. I 68420 (S.D.N.Y. 1954) (boycott by entertainers involved a labor dispute where Entertainers Guild members desired recognition as employees) ; Braddick v. Federation of Shorthand Reporters, 115 F. Supp. 550 (S.D.N.Y. 1953) (motion for summary judgment denied because status of shorthand reporters uncertain). Cf. NLRB v. Hearst Publications, 322 U.S. 111 (1944) (manipulation under the Wagner Act).

8. See Aetna Freight Line's v. Clayton, 228 F.2d 384 (2d Cir. 1955), cert. denied, 351 U.S. 950 (1956) (fact that union was trying to force its regulations on independent contractors who did a similar type of work did not prevent $\S 113$ of Norris-LaGuardia from applying). For a more thorough, though not so recent criticism, see Gottesman, Restraint of Trade-Employees or Enterprisers?, 15 U. CHI. L. Rev. 638 (1948). 
Attempting to meet this criticism, a federal district court has ruled that independent contractors may in some situations comprise a "labor" group and therefore be permitted to combine with an organization of employees. In United States v. Fish Smokers Trade Conncil, Inc., 9 the United States charged six smokehouses, various independent jobbers and a union primarily composed of smokehouse employees but including a few jobbers with a criminal violation of the Sherman Act. ${ }^{10}$ The employees, driver-salesmen for the smokehouses, claimed to be in direct competition with the jobbers who purchased from the smokehouses for resale. ${ }^{11}$ The government contended that, even if the employees' claims were correct, organization of independent contractors by a union violated the Sherman Act. While the jury's indecision precluded final disposition of the action, the court's instructions rejected this contention and suggested a test for determining the legality of such organization. ${ }^{12}$ The jury was charged not to rely solely on the presence or absence of an employer-employee relationship in classifying the independent contractors as a labor or non labor group. ${ }^{13}$ Rather, categorization was to depend on "whether the work done and the overall functions performed by the members of a group in an industry conflicts with or competes with the interests of union members employed in the same industry, and whether such work and functions bear a reasonable relationship to the earnings, hours, working conditions and job security of employees."14

As a generalization removed from the context of Fish Smo'kers, the "reasonable relationship" test could yield undesirable results. Services performed and prices charged by independent contractors at every level of distribution and production in the industry affect the terms on which employees work. ${ }^{15} \mathrm{~A}$ selfemployed retailer's willingness to sell at competitive prices, for example, conflicts with the production employee's interest in high industry profits facilitating demands for higher wages. ${ }^{16}$ But a "reasonable relationship" test which al-

9. Crim. No. 148-208, S.D.N.Y., Oct. 15, 1956 (subsequently restored to trial calendar). See Transcript of Record, pp. 1454-63, (discussing government's contention that the Aetna decision was not applicable because it contained certain elements of free speech).

10. Id. at pp. 1322-29 (government indictment).

11. See id. at pp. 1354-62, 1450-51.

12. The result of the original trial was a hung jury. Id. at pp. 1432-37. The case has been restored to the trial calendar and is now pending.

13. "In this case you will be called upon to decide whether the jobbers in this industry are a labor or a non labor group.... Whether a group is a labor or a non labor group is not determined solely by whether or not an employee relationship exists with an employer." Id. at pp. 1353-54.

14. Id. at p. 1354 .

15. See Sidney \& Beatrice Webb, Industrial Democracy 654-71. (1902). A union might want to organize all independent contractors in the industry. See LiNDBION, UNIONs and Capitalisa 103 (1949) (teamsters claim jurisdiction over "everything on wheels").

16. The unions' demand for more wages at any cost has often been noted. See AtKINs \& Lasswell, Labor Atritudes and Problemss 307 (1924) ("all we can get"); BakKe, The UNEMPLOYEd Worker 66 (1940) ("fair wages is more wages") ; Slichter, Labor After the IVar, in Postwar Economic Problears 241, 254 (Harriss ed. 1943) (unions use their bargaining power to their own advantage regardless of the interests of the nation). 
lowed a production union to organize retail outlets would undermine the Sherman Act without fostering the Norris-LaGuardia policies permitting a monopoly in the market where the employee sells his labor. ${ }^{17}$ The scope of the test must accordingly be limited to contractors in functional competition with, and directly substitutable for, union members. ${ }^{18}$ Under this approach, allowable unionization would not be confined to contractors who performed services for manufacturers employing union members. Entrepreneurs dealing with manufacturers who compete against employers might also be found functionally competitive. ${ }^{19}$ And while unionization of contractors who undertook substantial

See also Lindblom, Unions and Capitalism 172-76 (1949) (when competitive system makes union wages insecure, the union program calls for industry organization on a noncompetitive scale); e.g., Allen Bradley Co. v. Local 3, Int'1 Brotherhood of Electrical Workers, 325 U.S. 797 (1945).

Wage demands forcing a rise in prices may bring gains to workers in the industry concerned, but do so at the expense of other workers whose real wages fall through the rise in commodity prices. Beveridge, Fuld Exrployment in a Free Society 199 (1945). Furthermore, wages increasing faster than productivity may lead to inflation. PooL, WAGE Policy in Relation to Industrial Fiuctuations 73-85 (1938).

17. On the Sherman Act generally, see Report of the Attorney General's Natronal Comimittee to Study the Antitrust Laws 1 (1955) (hereinafter cited as AtT'y Gen. Rep.) ; Hodges, Antitrust Act and the Supreme Court 4 (1941); Walker, History of THE SHERMAN LAW 3 (1910). A labor market can extend beyond the dealings between employee and employer. The independent contractor often sells his labor directly to the purchaser of a commodity. Therefore, the physical market in which the independent contractor deals may be both a labor and product market. On the other hand, the employee's labor market does not extend beyond the functional limits of his occupation or those occupations which compete with his. Thus, although the retailer may be selling in a labor as well as a commodity market, he would not be operating in the same labor market as the employee. See Lester, Economics of LABor 93-127 (1947) ; TAFT, Econonics and ProbLEMS OF LABOR 82-83 (2d ed. 1948) (labor market is a concept, not a single recognizable institution).

18. This situation usually arises in the case of self-employed middlemen competing with employees in the distribution of the employer's product, e.g., the Fish Smokers case, or "employeeless" enterprises competing with employers of union members in retail sales. See Note, 40 Colunr. L. Rev. 1439, 1440-41 (1940).

The basis of the unions' demand to organize such independent contractors has long been recognized. See Gottesman, supra note 8 , at 651-57; Hearings Before the Joint Temporary National Economic Committee, 76th Cong., 3d Sess., pt. 31-A, 18176-77 (1939) ; Mason 215; Note, 42 Colum. L. Rev. 702, 703 (1942). The economic problems faced by the employee are also faced by the independent contractors who perform the same type of work. H.R. REp. No. 669, 72d Cong., 1st Sess. 2, 3, 6, 7 (1932) ; S. REp. No. 935, 72d Cong., 1st Sess. 8-10 (1932). Accordingly, the union member, obliged to follow regulations on hours and working conditions, occupies an underdog position when competing in the labor market with independent contractors who are not so restricted. See 20 B.U.L. REv. 732,735 (1940).

19. Prohibiting union regulation of competing independent contractors might induce employers to substitute the contractor for the employee. If the jobbers cannot organize for themselves, see note 3 supra, or be organized by an employees' union, see note 5 supra, the employer gains the advantage of bargaining with an individual rather than the more powerful group representative. Employers have demonstrated their willingness to redesignate employees as "independent contractors" in other contexts. See NLRB v. Blount, 131 F.2d 
functions beyond those discharged by employees might not be illegal, ${ }^{20}$ em-

585 (Sth Cir. 1942) (persons mining ore in return for a royalty held employees); Walling v. Woodbine Coal Co., 64 F. Supp. 82 (E.D. Ky. 1945) (attempt by employers to avoid Fair Labor Standards Act by contracting with each "employee" for the independent mining of a certain portion of a coal mine); Wolfe, Determination of Employer-Employee Relationships in Social Legislation, 41 CoLUM. L. Rev. 1015 (1941) (describing early attempts to classify employees as independent contractors to avoid social security). The TaftHartley Act makes employer substitution of independent contractors for employees an unfair labor practice when done to avoid the statutory obligation to bargain with the union. See Labor Management Relations Act, $\$ 8$ (a) (3), 49 STAт. 452 (1935), as amended, 29 U.S.C. $\S 158$ (a) (3) (1952). However, economic reasons for shifting from employees to independent contractors, by demonstrating that the employer had a purpose other than avoidance of his statutory obligation, constitute a defense to charges of violating $\S 8$ (a) (3). NLRB v. Adkins Transfer Co., 226 F.2d 324 (6th Cir. 1955). The doctrine has been so strained that a company can make a successful defense by pleading a "probable saving" without showing any statistical support. See NLRB v. Houston Chronicle Publishing Co., 211 F.2d 848 (5th Cir. 1954). Thus the burden of producing substantial evidence which indicates that the change in business methods was motivated by an intention to avoid the employer's bargaining obligations is on the union. Id. at 855; cf. New York State Labor Relations Board v. National Beauty Parlors, Inc., 180 Misc. 997, 45 N.Y.S.2d 36 (Sup. Ct. 1943) (renting beauty shop booths to former employees was an unfair labor practice under the state statute).

20. All independent contractors perform some additional functions. In certain situations, however, the basic work performed is essentially the same as that performed by the employee. See Schwartz v. Laundry \& Linen Supply Drivers' Union, 339 Pa. 353, 363, 14 A.2d 438, 445 (1940) (dissenting opinion), 89 U. PA. L. Rev. 241. (1940); note 18 supra.

No cases have been found involving independent contractor-employee unions under the Taft-Hartley Act, but the act is unlikely to pose any serious threat to legality. Such a union would be recognized by the NLRB. See NLRB v. Edward G. Budd Mfg. Co., 169 F.2d 571, 576 (6th Cir. 1948) (fact that persons other than employees are members does not prevent a labor organization which is otherwise qualified from continuing to function). The union is considered, however, to be the representative only of the employees. General Foods Corp., 110 N.L.R.B. 1088 (1954) (combined supervisors-employees union certified by the board to represent employees only). On the union's power to bargain for the contractors, see note 36 infra.

Since the Taft-Hartley Act refers solely to employees, see 49 Star. 450 (1935), as amended, 29 U.S.C. \$ $152(3)$ (1952), the independent contractor might not be protected from unfair practices on the part of the employer or union. If the employer refused to deal with him because of his union affiliation, the contractor could be without remedy. NLRB v. Inter-City Advertising Co., 190 F.2d 420 (4th Cir. 1951) (Board cannot rectify the firing of supervisors because of their union activities). On the other hand, such action might be considered a movement to discourage union membership generally in violation of $\S 8(1)$. Cf. NLRE v. Vail Mfg. Co., 158 F.2d 664 (7th Cir. 1947) (discharge of foremen to influence voting against the union is illegal). The independent contractor, however, could not be forced to join the union on pain of losing his source of livelihood as easily as could the employee in a union shop. The Labor Management Relations Act, $\$ 8(\mathrm{~b})$, states: "It shall be an unfair labor practice for a labor organization or its agents ... (4) to engage in, or to induce or encourage the employees of any employer to engage in, a strike or a concerted refusal ... to use ... handle or work on any goods ... or to perform any services, where an object thereof is: (A) forcing or requiring any employer or self-employed person to join any labor or employer organization. ..." 61. STAT. 141 (1947), 29 U.S.C. $\$ 158(\mathrm{~b})$ (1952). But see Chauffeurs Union, 116 N.L.R.B. 955 (1956) (work stoppage by in- 
ployee-independent contractor unions would be closely scrutinized to determine if their activities caused anticompetitive effects in markets other than labor. ${ }^{21}$

Union regulation of the organized contractor's pricing policies could not be considered an automatic indication of such anticompetitive effect. ${ }^{22}$ It has been urged that a combined union may regulate the working conditions of its contractor members, but that regulation of the prices they charge would violate the Sherman Act. ${ }^{23}$ True, unions customarily control hours, wages and other factors which affect the commodity price only indirectly; nevertheless, this contention must fail. ${ }^{24}$ The primary aim of labor's legal monopoly is control of wages. ${ }^{25}$ The prices independent contractors charge are determinative of the

dependent contractors to force unionization of other independents is not illegal under the Taft-Hartley Act since contractors are not employees; presumably no antitrust suit had been brought). Of course, other means, such as moral pressure and competing for the nonunion contractor's business would be legal, and, perhaps, effective. See Administrative Decision of NLRB General Counsel, No. 896, 2 CCH LAB. L. REP. ff 3850.65 (1954) (use of the "silent" treatment on officers of a rival union is not unlawftul).

For state court rulings on forcing independent contractors to join unions, see Riviello v. Journeymen Barbers Union, 109 Cal. App. 2d 123, 240 P.2d 361 (1952) (peaceful picketing for the purpose of compelling self-employed barber to become a restricted member of a union without full rights is illegal) ; Simon v. Journeymen Barbers Union, 11 N.J. 448, 94 A.2d 840 (1953) (same); Note, 24 U. CHr. L. Rev. 733, 735 (1957).

21. The past few years have revealed an increased vigilance on the part of the Department of Justice in prosecuting unions for nonexempted restraints on trade. Barnes, Unions and the Antitrust Lawes, supra note 5, at 136.

22. Price fixing, if not within the express exemption of another statute, is a per se violation of the Sherman Act. United States v. Socony-Vacuum Oil Co., 310 U.S. 150, 212-14, 218 (1940) (inquiry under the rule of reason ends when price fixing is involved); United States v. Trenton Potteries Co., 273 U.S. 392, 396-98 (1927) (reasonableness of prices fixed is immaterial) ; ATT'y GEN. REP. 12-13. This unconditional prohibition of price fixing has been attacked by foreign jurists. Machlup 204. It is defended by reference to the basic policy of the antitrust laws, which avoids government judgment on what prices are fair and leaves the determination of price as far as possible to the autonomous forces of the market. United States v. Trenton Potteries Co., supra at 397-98; Machlup 204.

23. Schwartz v. Laundry \& Linen Supply Drivers' Union, 339 Pa. 353, 14 A.2d 43S (1940), 20 B.U.L. Rev. 732 (1940). See also Apex Hosiery Co. v. Leader, 310 U.S. 469, 503-04 (1940) (dictum; union curtailment of price competition violates the Sherman Act).

24. Union control of the market price, although indirect, may be very effective. See United States v. American Federation of Musicians, 47 F. Supp. 304 (N.D. I11. 1942), aff'd per curiam, 318 U.S. 741 (1943) (union activities against record manufacturers and broadcasters designed to bar use of transcribed music in radio broadcasts is legal) ; MASON 198-99. In addition to control of hours, wages and working conditions, unions have other ways of manipulating the product market. See Hent, The Brotherhood of RaILway Clerks 216-17 (1937) (use of union's political power for enactment of legislation favorable to employer and his product); Lindblon, Unions and Capitaliss 100 (1949) (use of union's political power to gain high tariff rates for products which its members produce); Hochman, Union Job Control, in Unions, Management, and the Public $328-29$ (Bakke \& Kerr ed. 1948) (use of advertising to increase demand for a product). Union negotiations for wage increases have been directly linked with the pricing policies of an industry. IINDbLom, UnIONS aNd Capitalisar 102 (1949).

25. See Unions, Mantagenent, and the Public 655 (Bakke \& Kerr ed. 1948) (wages are of the greatest concern to employees); BAKKE, THE UNEArPLOYED WORKER 66 (1940) 
"wages" they receive, although elements of cost and entrepreneurial profit are also reflected in contractor prices. ${ }^{20}$ Competing employees can only control contractor "wages," and hence protect their own wage level, by regulating these prices. ${ }^{27}$ The very policies requiring Norris-LaGuardia protection for organization of employee-contractor unions necessitate granting such unions power to control the wage element in contractor profits through control of prices. ${ }^{28}$ But union price control should not be allowed to increase contractor profits more than necessary to equate their "wages" with collectively bargained employee wages. Entrepreneurs may not join together to benefit themselves, ${ }^{29}$ and even if some benefit accrues to employees, Norris-LaGuardia policies do not protect gains achieved through direct restraints on markets other than labor. ${ }^{30}$

No restraint could arise from the organization of contractors, however, if the market in which they sold remained essentially competitive. ${ }^{31}$ The union would then be able to influence contractor prices only through general power in the

(importance of wages for prestige as well as for purchasing power); HaRRISs, THE Amierican Economy 238 (1953) (hereinafter cited as HarRiss) (the union may be an end in itself to union officials, but rank and file members' interest is principally in more income). But see Slichter, Wage Policies of Trade Unions, in Unrons, Management, and the Publrc 670 (Bakke \& Kerr ed. 1948) (suggesting that generalizations on importance of wages are dangerous since each union has its own wage policy).

26. Certain of these costs are also borne by employees. Equipment depreciation costs, for example, are not solely a problem of independent contractors. Many employees, such as workers in the building trade's, have their own equipment. Note, 42 CoLuM. L. REv. 702, 703 n.7 (1942).

27. See Note, 24 U. CHI. L. Rev. 733, 738 (1957). If employees are not protected from the competition of independent contractors, they may have to accept lower wages or find themselves without jobs. See note 19 supra.

28. On an intrastate level, union contracts often fix prices directly. The barbers and cosmetics unions commonly follow the practice of setting employer prices. Leiserson, $R e-$ straints on Trade, in UnIons, MLANAGEMEnT, AND the Public 212 (Bakke \& Kerr ed. 1948). See Note, 24 U. Crr. L. Rev. 733, 737-38 (1957).

Recent bargaining objectives of the United Automobile Workers include demands not anly for higher wages but also for a reduction in the automobile manufacturer's prices. N.Y. Times, Aug. $23,1957, \S 1$, p. 1, col. 4, p. 6, col. 2 (reply by General Motors Corporation to the United Auto Workers on a request to cut auto prices $\$ 100)$.

29. See note 3 sippra and accompanying text.

30. See notes 44 infra, and 6,17 supra.

31. Organization of the independent contractors would have a tendency to lessen the number of sellers in the product market by combining all the contractors into what basically would be a single unit. If after organization, so many buyers and sellers of the product existed that no one buyer or seller could have any appreciable influence on the price by varying the amount which he offered to buy or sell, the market could be described as competitive. See Edwards, Marntaining Comipetition, Reguisites of a Government Policy 6-9 (1949); Harriss 486; Machiup 13-15. See also Reynolds, The Control of CoMrpetition IN CANADA 94-106 (1940) (examining the definition of cutthroat competition). Although purely competitive markets exist primarily in theory, markets often structurally approximate pure competition and behave in an essentially competitive fashion. See Clark, Toward a Concept of Workable Competition, in Readings in The Sociar. Control of Industry 452-58 (Am. Econ. Ass'n ed. 1942); Harriss 486-87; Machlup 13. Organization of all the contractors could destroy competition, however, by creating one 
labor market; ${ }^{32}$ it could not effect excess profits on the contractor's non-employee functions, sold in a market over which it has no control. ${ }^{33}$ Attempts to raise prices beyond levels necessary to the protection of employee wages would result in the contractor charging prices higher than his employee-hiring competitors and hence in his elimination. ${ }^{34}$ Moreover, unless the union could force

seller powerful enough to coerce the others. Whether a union would act in this manner is uncertain. Compare note 16 supra, with note 47 infra.

Some economists have insisted that powerful unions destroy the competitive price system by appropriating excess profits and hindering proper allocation of resources. See Linnblom, Unions and Capitalism 5 (1949) (unions will destroy the price system); MacHLUP 401 ("sabotages" the functioning of the system) ; Simons, Some Reflections on Syndicalism, 52 J. PoL. EcoN. 1 (1944) (prevent expansion of output). These views are virtually without factual support. MAson 204. Furthermore, even these economists admit that unions may be necessary for worker protection despite their effect on the competitive market. Lindblom, Unions and CaptTalisar 9-15, 19 (1949) ; Machlup 345-79.

32. With union control limited to the labor market, the combined union's activities in the product market would be no more anticompetitive than in the fully organized labor market where industry-wide bargaining prevails. At most, the union's control over product price competition is limited to equalizing labor costs among all sellers. Cox, Labor and the Antitrust Lazes-A Preliminary Analysis, 104 U. PA. L. REv. 252, 277-78 (1955) (industry-wide unionization diminishes but cannot eliminate labor cost as a competitive factor; both differences in productivity and varying use of labor-saving machinery prevent complete equalization of labor costs). Despite this tendency, industry-wide bargaining is still generally accepted. $I d$. at 275-79 (industry-wide bargaining may lead to inflation, but it does not eliminate competition); Lester \& RoBIE, WaGes under National and RegronaL Collective Bargaining 93-95 (1946) (wage decisions more sensible and farsighted with industry-wide bargaining) ; H.R. REp. No. 510, 80th Cong., 1st Sess. 36, 59 (1947) (rejection of proposed legislation to outlaw industry-wide bargaining). But sec Van Sickle, Indistry-Wide Collective Bargaining and the Public Interest, in UNIONs, MaNaGEMrent, AND THE PUBLIC 521, 526 (Bakke \& Kerr ed. 1948) (industry-wide bargaining fosters political and economic isolation, domestic regimentation and international conflict).

Furthermore, diminishing the variance between labor costs in a competitive industry does not limit the type of competition which antitrust policy is designed to preserve. As long as free entry into the market remains, price fixing, output limitations and customer allocation leading to excess profits and lazy management--the basic evils at which antitrust policy is aimed-cannot be utilized. Cox, supra at 279 .

33. In a competitive market, price is set by supply and demand; the seller has no control. Harriss 487; Samiuelson, Economics 440 (3d ed. 1955); Chamiberitn, The Theory of Monopolistic Competition 16-21 (7th ed. 1956). His only method of achieving profit maximization is to adjust his output. Id. at 18; HarRISS 487; Note, 66 YALE L.J. 243, 253 n.48 (1956).

34. If a seller raises his price above that set by the competitive market, he will lose his buyers. Harriss 488; Machlup 14; see also Stocking \& Watkins, Monopoly and Free ENTERPRISE 9 (1951) (hereinafter cited as Stocking \& WatKINs). If the contractor has a cost advantage in dealing with some customers, however, he can raise his price without losing these' customers to employer competitors. But unless the contractor raises his price only to these buyers, he will lose his business in the area where he has no advantage over the employer. Contractor price rises greater than cost advantage will, of course, result in complete loss of the market. Such differences in efficiency are often the reason for a structure containing both contractors and employees. Thus, in the Fish Smokers case, the independent contractors were apparently more efficient in servicing small firms and the smokehouse 
employers to accept a fixed ratio of employees to contractors, ${ }^{35}$ it would not be able to achieve excess profits for contractors by forcing down the prices at which they buy. ${ }^{36}$ The employer would merely substitute employees for contractors to protect his own profit margins. ${ }^{37}$ And a fixed ratio designed to save

employees more efficient in deliveries to chain stores and restaurants. See Transcript of Record, p. 1333, United States v. Fish Smokers Trade Council, Inc., Crim. No. 148-208, S.D.N.Y., Oct. 15, 1956 (subsequently restored to trial calendar).

35. Such a measure would be a proper subject of collective bargaining. The TaftHartley Act allows unions of employees to bargain collectively with the employer on the amount of dealings he will have with independent contractors when the employees are capable of performing the same type of work as the contractors. Timken Roller Bearing Co., 70 N.L.R.B. 500 (1946). State courts have permitted employee unions to force agreements by employers to conduct their businesses solely through the use of employees. Davis v. Yates, 32 N.E.2d 86 (Ind. 1941) ; Ellingsen v. Milk Wagon Drivers' Union, 377 Ill. 76, 35 N.E.2d 349 (1941) (dictum). It has been urged that such an agreement should present no serious antitrust problems. See Note, 42 Colum. L. Rev. 702, 703 (1942). But see United States v. Milk Drivers Union, 6 CCH LAB. L. Rep. đf 70934 (D. Minn. Aug. 30, 1957) (contract clause requiring employers to forego sales to any independent contractors entering business after two years from the contract date is a violation of the Sherman Act). See text at note 38 infra.

36. Whether under the Taft-Hartley Act the union could successfully compel the employer to bargain over the terms on which he sold supplies to the independent contractors is unclear. Although no rulings have been made on this particular point, various lines of reasoning have been suggested in cases in which unions containing employees have bargained over the terms of employer contracts with nonemployee union members. The employer is required to bargain collectively in matters concerning wages, hours and working conditions of employees. 49 Stat. 453 (1935), as amended, 29 U.S.C. \$ 158 (1952). Exceptional as well as routine matters affecting the terms of employment are subjects of compulsory bargaining. Order of Railroad Telegraphers v. Railway Express Agency, Inc., 321 U.S. 342 (1943). The broad scope given to "exceptional matters" indicates employee relations with nonemployees could be included. Timken Roller Bearing Co., supra note 35 (union control of amount of employer's dealings with independent contractors); cf. NLRB v. Phoenix Mut. Life Ins. Co., 167 F.2d 983 (7th Cir. 1948) (insurance salesmen could use concerted activity to communicate their views to their employer concerning appointment of a cashier). The union can argue that its control of prices charged to independent contractors is necessary for employees' aid and protection. See NLRB v. Retail Clerks Int'1 Ass'n, 21.1 F.2d 759, 765 (9th Cir. 1954) (dissenting opinion; union cannot force employer to bargain for supervisors but can, in the interest of employees, make good faith demands affecting the supervisors). See also NLRB v. Reynolds Int'l Pen Co., 162 F.2d 680 (7th Cir. 1947) (employees who left work because of personal dissatisfaction with a foreman were not protected by the Taft-Hartley Act; basis for dispute must be mutual aid of employees, not dislike of nonemployee). Of course, employees can always achieve their aims by bargaining for their own wages in terms relating to the profits of the independent contractors. Furthermore, although not required to bargain with a group representing nonemployees, the employer may voluntarily do so. NLRB v. Retail Clerks Int'l Ass'n, 203 F.2d 165 (9th Cir. 1953) (dictum).

37. In a substantially competitive market, the producer is forced to use the most efficient means of production since the commodity price will approximate average cost of production plus a normal return on investment. HarRiss 495 . If the employer can make sales at a lesser cost through employees than through independent contractors, he will shift to the more efficient means. See note 19 supra. 
contractors from a shift to employees would violate the rule against self-organization by the contractors since they would be the sole beneficiaries of the plan. ${ }^{3 s}$

When organization results in oligopoly among sellers of the contractor's product, however, union control of prices may give rise to antitrust violations. ${ }^{39}$ While union announcements of higher contractor prices can have no effect in a competitive market, they may, in a market containing few sellers, bring about general industry price fixing. ${ }^{40}$ Such a situation would present difficult alternatives. Courts could consider that the monopoly dangers inherent in the structure are too great to justify protection of Norris-LaGuardia policies. ${ }^{41}$ But

38. Given a combined union, the desirability of a similar provision designed to aid employees is questionable. It would protect employees who are in an inferior position because of their own inefficiency rather than the substandard working conditions of independent contractors. In any event, a fixed ratio for the benefit of employees would presumably be legal under the Taft-Hartley Act. See note 35 supra.

39. An oligopoly exists when there are so few sellers in an industry that each realizes that his own output and price decisions affect his competitors, and that their individual decisions affect him. Harriss 509; Mason 348; Fellaner, Conspetition Among the Few 41-50 (1949).

40. For an oligopoly to exercise full profit maximization in monopolistic fashion, the firms involved must act as a single group. Harriss 510. Collusion is not essential. ATT'Y Gen. Rep. 36 (action by conscious parallelism); Fellner, CoMspetition Ajrong the FEW 33-34 (1949) (action through quasi-agreement); MAson 348 (achieving result of joint action without collusion). Prior announcement of price and output changes may provide the means for tacit agreement. See, e.g., the "trade information" cases: American Column and Lumber Co. v. United States, 257 U.S. 377, 410 (1921) (exchange of daily sales reports, monthly production reports and price lists was evidence of tacit agreement to fix prices) ; United States r. American Linseed Oil Co., 262 U.S. 371 (1923) (same); Maple Flooring Manufacturers Ass'n v. United States, 268 U.S. 563, 586 (1925) (neither the character of the information circulated nor the use made of it indicated that its necessary effect would be a restraint upon commerce) ; Cement Manufacturers Protective Ass'n v. United States, 268 U.S. 588, 603-04 (1925) (although defendants had the combined power to $f x$ prices, a careful analysis of their reaction to the circulated information showed that they did not do so) ; Sugar Institute, Inc. v. United States, 297 U.S. 553 (1936) (requiring public announcement of all price changes and members' adherence to announced prices limited price competition in violation of the Sherman Act). Absent advance knowledge of competitors' reactions, firms are unlikely to change their prices to gain maximization of industry profits; such price changes may be misinterpreted as being directed toward aggressive competition and result in general price warfare. FelLner, CoMpetrtion AMong the FEW 177-80 (1949); Note, 66 YALE L.J. 1251, 1252 n.5 (1957).

41. This consideration would be in accordance with a possible interpretation of American Tobacco Co. v. United States, 328 U.S. 781 (1946), and United States v. Aluminum Co., 148 F.2d 416 (2d Cir. 1945) (sitting as court of final judgment). See Rostow, A National Policy for the Oil INdustry 136-37 (1948) (cases imply oligopoly to be an illegal market structure); Machlup 224-25 (same); But see Stocking \& Watrins 288-96, 304-13 (doubts validity of this interpretation although supporting it on policy grounds). In Alcoa, the court rejected the notion that the existence of unexerted monopoly power in a single seller did not violate the Sherman Act. United States v. Aluminum Co., supra at 428-30 (in effect overruling United States v. International Harvester Co., 274 U.S. 693, 708 (1927)). Similarly in American Tobacco, the Court ruled that a few sellers jointly possessing power to raise industry prices or exclude competition violate the Sherman Act 
this conclusion discriminates against employees merely because their employers were, even before contractor unionization, nearly oligopolistic. ${ }^{42}$ Alternatively, the courts could undertake difficult case by case analysis to determine if the oligopoly behaves in a competitive or monopolistic fashion. ${ }^{43}$ In such analysis, determination of whether union price announcements tended to initiate industry price changes would be especially relevant.44 Similarly, the level of profits

even though that power has never been exercised. American Tobacco Co. v. United States, supra at $811-15$.

Dissolution of oligopolies has been suggested. See Stocking \& Watkins 180-83. Yet another commentator has noted the absence of proof that twenty firms in an industry will compete more effectively than four. See Weston, The Role of MERGers in the Growtr of Large Firms 89-90 (1953). But see Bowman, Toward Less Monopoly, 101 U. PA. L. Rev. 577, 634-35 (1953) (greater number of competitors more likely rather than less likely to bring about competitive results); Note, 66 Y ALE L.J. 1251, $1256 \mathrm{n} .15$ (1957) (agreement effected more easily among a small group of competitors). In the present status of the law, violation of the Sherman Act need not always require dissolution. Courts do not have to change a market structure if they believe it can operate competitively when certain practices are eliminated. See, e.g., United States v. National Lead Co., 332 U.S. 319 (1947) (collusive restraints removed but no dissolution ordered; presumably because competition had been effective in the industry's past).

42. If an oligopoly exists after unionization of the independent contractors, the market before unionization probably consisted of a few large firms and many small firms-the independent contractors-and was essentially oligopolistic. Since the big firms could force out independent contractors merely by refusing to deal with them, the existence of the contractors could not serve as a strenuous deterrent to the exercise of monopoly control by the big firms. See Note, 66 Y ALE I.J. 1251, 1252 n.5 (1957).

43. Similar ad hoc factual analysis was used in the "trade information" cases, note 40 supra. In each case, the Court analyzed such factors as position and control of market, type of commodity sold in the market and the extent competition seemed to be primarily based on price. Although various theoretical principles have been developed, generalizations about oligopoly conduct are difficult, and particular attention must be paid to the individual industry. MASON 60 (theory of oligopoly is a "ticket" to institutionalist economics); Galbraith, Monopoly and Concentration of Economic Power, in A SURVEy of CoNTEMIPORARY Economics 99, 102 (Ellis ed. 1948) (generalization is impossible because oligopoly, unlike competition, deals with individual behavior rather than mass behavior); Bain, Market Classifications in Modern Price Theory, 56 Q.J. Econ. 561, 568 (too varied to be treated systematically); see Srocking \& WATKINs $108 \mathrm{n.57}$ (antitrust policy can only be applied on a case by case basis).

An oligopoly is unlikely to operate in a purely competitive fashion. It may, however, behave in a fairly competitive manner. Such behavior has been termed workable competition. Mason 353-54; Clark, Toward a Concept of Workable Competition, in Readings in the Social Control of Industry 452 (Am. Econ. Ass'n ed. 1942); Atr'y Gen. Rep. 320-39 (criteria of workable competition). Commentators have suggested that courts are moving toward accepting criteria of workable competition as standards for determining whether unreasonable restraint of trade exists. See MASon 362; Stocking, On the Concept of Workable Competition as an Antitrust Guide, 2 Antrtrust Butr. 3 (1956). See also United States v. National Lead Co., 332 U.S. 319 (1947). But see National Lead Co. v. FTC, 227 F.2d 825, 834 (7th Cir. 1955), rev'd in part, 352 U.S. 419 (1957) (existence of other forms of competition does not justify lack of price competition).

44. Assuming an equation of employee wages with the contractor's profits, no "wage" need would exist for independent contractors to raise their prices. Any price changes in- 
derived by independent contractors could be compared with wages earned by employees performing comparable functions; any added capital or intangible investment by the contractors would, of course, have to be considered.45 Utilization of this approach would encourage employees to protect their wage structure by organizing contractors but discourage them from using the organization to gain monopolistic power outside the labor market. ${ }^{46}$ In addition, the knowledge that combined unions would be closely scrutinized might serve as an incentive for the union to act as a "maverick" causing the oligopoly to behave competitively. ${ }^{47}$

itiated by the contractors could only be evidence of an intent to use their new-found organizational power to benefit themselves through exercise of monopolistic control over the market. This would frustrate the established rule against independent contractors organizing for their own benefit. See note 3 supra and accompanying text. Moreover, cooperation of employers would be needed, for unless they followed the price rise, contractors would have to retreat. And price changes by the employers could benefit the employees by enabling them to demand higher wages because of increased employer profits. But since whatever benefits employees derived would be based on cooperation between union and employers in fixing prices, the basic policy of Allen Bradley Co. v. Local 3, Int'l Brotherhood of Electrical Workers, 325 U.S. 797 (1945), would be violated. See note 6 supra. The contractor would only be justified in raising his prices when increased wages forced the employer to raise his prices. Even an increase in wages, however, may not result in an increase in commodity prices. Under certain conditions, an employer might absorb increased labor costs. MachluP 400 (listing four characteristics of industries in which this will occur). In such a situation, the contractor would not be justified in raising his own prices.

Changes in price could easily be traced because they are usually not very frequent in an oligopolistic market structure. MAson 348 (very infrequent); Fellner, Competition Among THE FEw 180 (1949) (may produce a higher degree of price rigidity than would exist under a monopoly); see note 40 supra. On the other hand, rapid fluctuation may occur over a short period of time as a result of price warfare. Ibid. But during such a period, competition would reign and the court need not be forced to consider the changes.

45. Profit has long been e'stablished as an excellent criterion for determining if workable competition exists. Machlup 490-97; Mason 368; Bain, The Profit Rate as $A$ Measure of Monopoly Power, 55 Q.J. Econ. 271 (1941). Courts have acknowledged profits as such an index. See American Tobacco Co. v. United States, 328 U.S. 781, 797, 806 (1946). But see United States v. Aluminum Co., 148 F.2d 416, 426-27 (2d Cir. 1945); ATr'y GeN. REP. 50 (suggesting that profits are primarily useful in leading to other criteria).

Any capital invested by employees would, of course, be relevant to the comparison between contractor profits and wages. See note 26 supra.

46. This analysis would apply mutatis mutandis to oligopsony. See FenLNER, ConPETITION Among the FEW 10-12 (1949) (similar approach may be used to analyze both oligopoly and oligopsony). Combined unions posing oligopsony danger would occur, for example, if drivers for a few large retail chains purchased fish from various smokehouses, and unionized independent contractors also purchased fish from smokehouses for resale to retail outlets.

47. The possibility of antitrust prosecution is a constant deterrent to illegal actions by groups in the business world. Cf. Mason, The Effectiveness of the Federal Antitrist Laws: A Symposium, 39 Axr. Econ. REv. 689, 713 (1949). When an industry knows that it specifically is being observed, its behavior may be altered considerably. Tennant, The Cigarette Industry, in The Structure of American Industry 326, 347, 358 (Adams rev. 
Within these limitations, organization of contractors by employees seems entirely consistent with the existing balance of policies between the Norris-LaGuardia Act and the antitrust laws. Norris-LaGuardia sought to remove all legal obstacles to employees increasing their bargaining power by joint association. ${ }^{48}$ Where a significant number of employees in good faith desire to initiate organizational activity for their own benefit, they should be allowed to organize all workers who threaten the bargaining power granted them by the act. ${ }^{49}$ The legal category of the workers-employee or independent contractor - should not be determinative, for it has no bearing on the impact of such an unorganized group on the bargaining power of the employees. ${ }^{50}$ The reasonable relationship test advanced in Fish Smokers, restricted by the requirement of functional competition, seems admirably suited to permitting desirable organization. However, antitrust policies require some limitations on the activities of combined unions once organized. Such limitations, coupled with continued scrutiny of these unions, would protect the consumer from monopolistic practices not sanctioned by the Norris-LaGuardia Act for the protection of the workingman.

ed. 1954) (firms in the cigarette industry have followed a cautious pricing policy since they were convicted of violating the Sherman Act).

Furthermore, the necessity of maintaining morale and cohesiveness in a large organization limits the union's ability to act as a rational economic group and may decrease the desire for monopoly profits when they imply public disrepute. See Mason 202; Bakke, Why Workers Join Unions, in Unions, Management, AND the Public 41 (Bakke \& Kerr ed. 1948) (social desires and self-respect as reasons for union membership); Golden \& Ruttenberg, Motives For Union Membership, in id. at 49 (desire to be somebody as a reason for union membership). Such factors might make "maverick" behavior more likely. But see Machuup 398-99 (insisting that unions not only will not break up monopolies but may seek to increase and consolidate an employer's monopolistic position).

Existence of a maverick firm which refused to join in quasi-agreement has in the past been responsible for competitive oligopolies. HarRIss 510; Stocking \& Watkins 114-15. For an example of maverick activity, see National Steel; $A$ Phenomenon, Fortune, June 1932 , pp. 31, 36.

48. See note 1 supra.

49. A court could justifiably prevent a union of a few employees from organizing a large group of contractors on the basis that such an organization would pose a greater threat of antitrust violation than the protection of the few employees warranted. Cf. Local 309, Int'l Brotherhood of Teamsters v. Hanke, 339 U.S. 470, 475-77 (1950) (significance of the union's interest must be weighed against the value of the "self-employer" as a preventitive of excessive concentration of economic power).

Also, courts should inquire into who is organizing whom. The union must organize the independent contractors for the employees' benefit, not merely because the independent contractors desire to be organized. See note 3 silpra and accompanying text. See also Note, 24 U. CHI. L. Rev. 733, 738 (1957).

50. See notes 18,19 supra. 